\title{
Shelter or Transitional Living Situation
}

National Cancer Institute

\section{Source}

National Cancer Institute. Shelter or Transitional Living Situation. NCI Thesaurus. Code C159749.

Indicates that a person lives or lived in an emerg ency shelter or in transitional housing. 